\title{
MORDEDURAS: EXPERIÊNCIA DE PREVENÇÃO EM ESCOLA
}

(Bites: experience of prevention in school)

\author{
Bruno Pedon Nunes, Larissa Rachel Wolf, Rita de Cassia Maria Garcia
}

Universidade Federal do Paraná, Curitiba, Paraná, Brasil.

\section{*Correspondência: brunonunes@ufpr.br}

RESUMO: Os seres humanos e os cães vêm se relacionando há pelo menos 20 mil anos. A interação dos seres humanos com os cães traz inúmeros benefícios para a saúde física e psicológica de ambas as espécies. Apesar disso, essa relação cada vez mais próxima tem implicações diretas e pode trazer consequências negativas como abandono, zoonoses e aumento da incidência de agressões e mordeduras, especialmente no meio urbano. O cão é mostrado como a mais frequente espécie agressora aos humanos. Nesse contexto, as mordeduras dos animais são preocupantes devido à possibilidade de transmissão da raiva, que se trata de uma zoonose com altos índices de letalidade e que representa sério agravante na saúde pública. Além disso, variadas infecções podem ser causadas por bactérias de espécies patogênicas presentes na saliva dos animais. Segundo o IBGE, no período de 2009 a 2013, 391 mil atendimentos antirrábicos no Brasil foram notificados a partir de agressões a crianças na faixa etária entre cinco e nove anos. As crianças são as vítimas mais comuns de mordidas de cães, $70 \%$ dos ataques fatais de cães e mais da metade das mordidas que requerem atenção médica envolvem crianças. O presente estudo objetivou desenvolver programa educativo para a prevenção de mordeduras em escola pública de ensino fundamental. Toda a ação educacional foi realizada baseando-se no material " 5 chaves para prevenir mordidas de cães", desenvolvido pela Proteção Animal Mundial (WAP), em associação a Aliança Global para o Controle da Raiva (GARC) e Organização Pan-Americana da Saúde (OPAS). O estudo foi realizado em escola pública municipal no município de Pinhais, localizado na região metropolitana de Curitiba, a oito quilômetros da capital. As ações educacionais foram realizadas durante dezembro de 2017, englobando 464 crianças matriculadas e cursando do $1^{\circ}$ ao $5^{\circ}$ ano do ensino fundamental, com idade entre cinco e nove anos. As crianças receberam palestras de 15 minutos de duração sobre guarda responsável, bem estar animal e prevenção de mordeduras, utilizando-se das ilustraçoes presentes no material para exemplificação, seguida por simulação das cincos chaves de forma lúdica pelas crianças, com duração de cinco minutos. A fim de educar sobre os comportamentos humanos que desencadeiam a agressão expressada pelo animal, salienta-se a importância do médico veterinário como mediador da relação e distribuidor de conhecimento.

Palavras-chave: cães; crianças; mordidas; raiva; zoonoses

\section{Referências}

BRASIL. Ministério da Saúde. Secretaria de Vigilância em Saúde. Situação Epidemiológica - Dados. Perfil dos atendimentos antirrabicos humanos, Brasil, 2009-2013. 2016. Disponível em: <http://portalarquivos2.saude.gov.br/images/pdf/2016/julho/29/2016-010.pdf>. Acesso em: 30/09/2020.

PROTEÇÃO ANIMAL MUNDIAL - WAP. 5 chaves para prevenir mordidas de cães. 2015. Disponível em: <https://www.worldanimalprotection.org.br/not\%C3\%ADcia/5-chaves-para-prevenirmordidas-de-caes >. Acesso em: 30/09/2020. 